18

\title{
Люминесцентные и фотоэлектрические свойства гибридных структур на основе многослойного графена и OD и 2D полупроводниковых квантовых нанокристаллов
}

\author{
() И.А. Резник ${ }^{1}$, А.С. Златов ${ }^{1}$, П.О. Ильин ${ }^{1}$, Р.А. Заколдаев ${ }^{1}$, С.А. Мошкалёв ${ }^{2}$, А.О. Орлова ${ }^{1}$ \\ ${ }^{1}$ Университет ИТМО, \\ 197101 Санкт-Петербург, Россия \\ ${ }^{2}$ Universidade Estadual de Campinas (Unicamp), \\ SP 13083-970 Campinas, Brasil \\ e-mail: ivanreznik1993@mail.ru
}

Поступила в редакцию 09.02.2020 г.

В окончательной редакции 09.02.2020 г.

Принята к публикации 28.02.2020 г.

\begin{abstract}
Установление закономерностей механизмов, лежащих в основе взаимодействия наноструктурированных материалов - одна из важнейших задач на пути к созданию нового поколения эффективных фотовольтаических устройств. В данной работе исследуются люминесцентные и фотоэлектрические свойства гибридных структур, сформированных на основе многослойных графеновых нанолент и полупроводниковых квантовых нанокристаллов 0D размерности, квантовых точек типа ядро/оболочка $\mathrm{CdSe} / \mathrm{ZnS}$ и 2D размерности, нанопластин CdSe. Показано, что мультиэкспоненциальный распад экситонной люминесценции нанопластин $\mathrm{CdSe}$ при комнатной температуре обусловлен наличием замедленной люминесценции, обусловленной наличием ловушечных состояний на поверхности нанопластин. Установлено, что в сухих слоях нанопластин на диэлектрической подложке и в составе гибридных структур с графеновыми нанолентами эффективность замедленной экситонной люминесценции нанопластин увеличивается. Продемонстрировано, что скорость нарастания фотопроводимости в гибридных структурах на основе CdSe нанопластин на порядок превышает скорость данного процесса в аналогичных структурах на основе $\mathrm{CdSe} / \mathrm{ZnS}$ квантовых точек, что указывает на формирование эффективного канала передачи энергии/заряда от нанопластин к графеновым нанолентам.
\end{abstract}

Ключевые слова: многослойные графеновые наноленты; квантовые 0D и 2D нанокристаллы селенида кадмия, экситонная люминесценция, фотоэлектрические свойства, перенос энергии/заряда.

DOI: $10.21883 /$ OS.2020.06.49403.66-20

\section{Введение}

Гибридные наноструктуры, сочетающие в себе уникальные свойства нанообъектов разной природы, позволяют создавать новые функциональные материалы с улучшенными оптоэлектронными и функциональными свойствами, которые могут быть целенаправленно изменены в зависимости от области их применения. Преимуществом структур на основе наноматериалов перед объемными материалами и микрочастицами является возможность точной регулировки физических параметров, высокие значения эксплуатационных характеристик, незначительные тепловые потери из-за малой величины электрон-фононного взаимодействия, а также низкие затраты на производство [1]. В качестве таких нанообъектов могут выступать ультратонкие двумерные наноматериалы (например, графен и его аналоги), металлические наночастицы, полупроводниковые нанокристаллы (НК). Развитие методов коллоидного синтеза открыло возможность получать полупроводниковые НК не только разного химического состава и размера, но и различной формы, которые можно легко внедрять в различные матрицы, создавать комплексы и наносить их на диэлектрические и проводящие подложки [2]. Следует отметить, что среди многообразия коллоидных люминесцирующих квантовых НК разного химического состава, формы и размерности сегодня только для ограниченного класса НК, которые принято называть „классическими“ или „традиционными“ и к которым в первую очередь относятся квантовые точки (KT) $\mathrm{CdSe}, \mathrm{CdS}$ и $\mathrm{CdTe}$, установлены основные закономерности люминесцентных, электрических и фотофизических свойств в состоянии коллоидного раствора, в различных матрицах и в составе гибридных структур с участием органических молекул, металлических, полупроводниковых, магнитных и диэлектрических наночастиц [3]. Для подавляющего числа различных НК, синтезированных в течение последних пяти лет, сегодня отсутствуют физические модели, связывающие наблюдаемые экспериментально свойства НК с теоретически предсказанным откликом НК на внешнее возмущение, включая электромагнитное излучение, магнитное и электрическое поле. Класс двумерных полупроводниковых НК - нанопластины (НП) - один из наиболее ярких примеров того, что в теории многообещающие свойства НП не смогли быть реализованы в должной мере. В сравнении с 0D и 1D квантовыми HК, квантовыми точками и квантовыми стержнями, 
НП обладают более узкой полосой экситонной люминесценции, отсутствием стоксова сдвига, существенно большей силой осциллятора и более высокой скоростью излучательной релаксации возбужденных носителей [4]. Такие свойства делают данные НК перспективными для применения в качестве активных сред оптоэлектронных устройств, в частности, лазеров, однако к настоящему времени экспериментально не удалось продемонстрировать преимущества НП в конечных устройствах $[5,6]$. В первую очередь данное обстоятельство обусловлено тем, что НП характеризуются самым большим отношением площади поверхности к объему из всех НК. Это обстоятельство приводит к тому, что роль поверхности НП играет ключевую роль во взаимодействии данного типа НК с ближайшем окружением. В связи с этим установление физических механизмов взаимодействия НП между собой и проводящими двумерными материалами в гибридных структурах, является необходимым для их дальнейшего эффективного применения в составе оптоэлектронных устройств.

В данной работе сформированы гибридные структуры на основе полупроводниковых НК (КТ CdSe/ZnS и НП $\mathrm{CdSe})$ и многослойных графеновых нанолент. Проведены исследования фотофизических и фотоэлектрических свойств полученных гибридных структур.

\section{Материалы и методы}

В качестве растворителей для коллоидных НК в работе были использованы метанол и хлороформ фирмы „Вектон“ (Россия). Графеновые наноленты растворялись в метил-2-пирролидоне фирмы „Компонент-реактив“ (Россия). Все растворители использовались без предварительной отчистки. Для оценки чувствительности гибридных структур НП/графеновые наноленты на азотосодержащие молекулы были использованы пары $25 \%$ раствор водного аммиака фирмы „Вектон““.

В качестве коллоидных НК использованы гидрофобные полупроводниковые коллоидные КТ типа ядpo/оболочка $\mathrm{CdSe} / \mathrm{ZnS} \mathrm{c}$ максимумом люминесценции на $590 \mathrm{~nm}$, синтезированные методом горячей инжекции [7] и стабилизированные молекулами олеиновой кислоты. Средний диаметр ядра КТ составил $4.0 \mathrm{~nm}$. Также были использованы полупроводниковые коллоидные НП $\mathrm{CdSe}$, стабилизированные молекулами олеиновой кислоты, синтезированные согласно [8,9]. Толщина CdSe HП составляла $1.9 \mathrm{~nm}$, что соответствует 5 монослоям CdSe; латеральные размеры составляли $300 \mathrm{~nm}$. В качестве компонента гибридных структур, обеспечивающего высокую мобильности носителей зарядов, использовались многослойные графеновые наноленты, характеризующиеся латеральными размерами порядка $20-50 \mu \mathrm{m}$, шириной $1-5 \mu \mathrm{m}$ и толщиной $10 \mathrm{~nm}$ производства Nacionale de grafite (Бразилия).

Регистрация электронных спектров поглощения и люминесценции коллоидного раствора НК производилась на спектрофотометре Shimadzu UV-Probe 3600 и спектрофлуориметре Cary Eclipse (Varian), соответственно. Кинетика люминесценции НК в коллоидном виде и в виде сухих слоев на диэлектрической подложке и многослойных графеновых нанолент в составе гибридных структур анализировалась с использованием люминесцентного микроскопа Micro Time 100 (PicoQuant).

Морфология сухих слоев НК и гибридных структур на их основе была исследована с помощью электронного сканирующего микроскопа Merlin (Zeiss), атомносилового микроскопа Solver PRO-M (NT-MDT) и с помощью конфокального люминесцентного микроскопа LSM-710 (Zeiss).

Для исследования электрических свойств графена и гибридных структур НК/Графеновые наноленты использовался пикоамперметр Keithley 2636B (Keithley Instruments), который с помощью ПО и микроконтроллера был синхронизирован с внешним источником лазерного излучения с длиной волны $405 \mathrm{~nm}$ и ПК. Мощность падающего на образец излучения регулировалась с помощью поляризатора, ориентированного в плоскости поляризации падающего лазерного излучения. Для оценки мощности падающего на образец излучения использовался измеритель мощности излучения PM100 USB фирмы Thorlabs. Время облучения лазером и время релаксации в темноте гибридных структур при исследовании фотоотклика составляло $30 \mathrm{~s}$. Мощность лазерного излучения при исследовании фотоэлектрических свойств гибридных структур составила $5 \mathrm{~mW}$. Напряжение, подаваемое на контакты подложек с гибридными структурами, составило $1 \mathrm{~V}$.

Оценка квантового выхода люминесценции НК производилась на основании полученных спектров поглощения и люминесценции коллоидных растворов НК и эталона. В качестве эталона был выбран раствор родамина 6Ж, квантовый выход люминесценции которого составляет 95\% [10]. Квантовый выход люминесценции КТ был рассчитан по формуле (1) относительно референтного образца - родамина 6Ж. Квантовый выход люминесценции НП был рассчитан относительно референтного раствора КТ также по формуле (1). Результаты расчетов приведены в таблице.

$$
\frac{\varphi_{N C}}{\varphi_{r e f}}=\frac{I_{N C} n_{N C}^{2} D_{r e f}}{I_{r e f} n_{r e f}^{2} D_{N C}},
$$

где $\varphi_{N C}$ и $\varphi_{r e f}-$ квантовый выход люминесценции образца (НК) и эталона, $I_{N C}$ и $I_{r e f}-$ интегральные интенсивности люминесценции образца и эталона, соответственно; $n_{N C}$ и $n_{r e f}$ - показатели преломления растворителей образца и эталона, $D_{N C}$ и $D_{r e f}-$ оптическая плотность образца и эталона на длине волны возбуждения люминесценции.

Экспериментальные кривые затухания люминесценции НК были аппроксимированы мультиэкспоненциаль- 
$a$

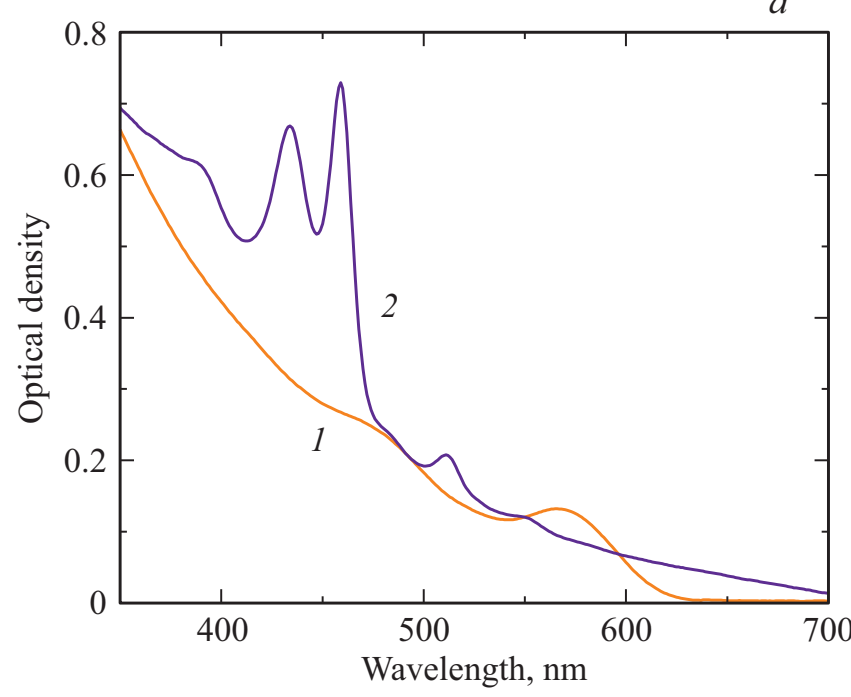

$b$

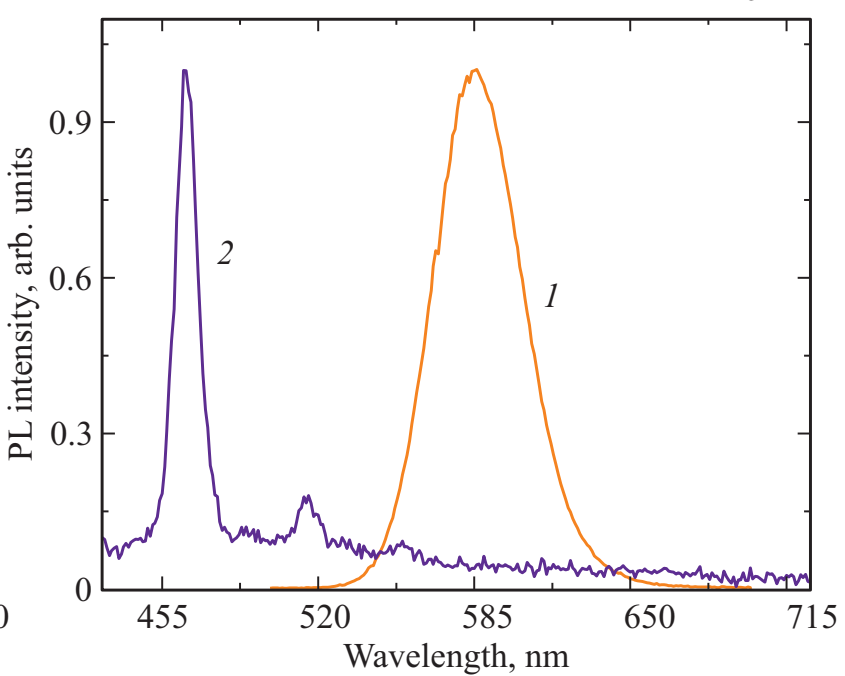

Рис. 1. Спектры поглощения (a) и люминесценции $(b)$ растворов $\mathrm{CdSe} / \mathrm{ZnS}$ KT $(1)$ и CdSe НП (2). Длина волны возбуждающего света $405 \mathrm{~nm}$.

Люминесцентные свойства НК

\begin{tabular}{c|c|c|c|c|c|c|c|c}
\hline НК & Амплитуда $A_{1}, \%$ & $\tau_{1}, \mathrm{~ns}^{2}$ & Амплитуда $A_{2}, \%{ }^{1}$ & $\tau_{2}, \mathrm{~ns}^{2}$ & Амплитуда $A_{3}, \%{ }^{1}$ & $\tau_{3}, \mathrm{~ns}^{1}$ & $\left\langle\tau_{3}\right\rangle, \mathrm{ns}^{2}$ & $\varphi, \%{ }^{3}$ \\
\hline КТ & 31 & $3.4 \pm 0.1$ & 60 & $15.1 \pm 0.1$ & 9 & $42.1 \pm 0.1$ & $21.7 \pm 0.1$ & 15 \\
НП & 75 & $0.8 \pm 0.1$ & 20 & $6.4 \pm 0.1$ & 5 & $44.6 \pm 0.1$ & $25.4 \pm 0.1$ & 5.7
\end{tabular}

Примечание. ${ }^{1}$ Амплитуда вклада люминесценции и характеристическое время затухания люминесценции рассчитаны по формуле (2).

${ }^{2}$ Средневзевешенное время затухания люминесценции рассчитано по формуле (3).

${ }^{3}$ Относительный квантовый выход рассчитан по формуле (1).

ной функцией согласно формуле (2):

$$
y=y_{0}+\sum_{i} A_{i} \exp \left(-\frac{x-x_{0}}{\tau_{i}}\right),
$$

где $A_{i}-$ амплитуда, $\tau_{i}-$ характерное время $i$-й компоненты затухания люминесценции.

Средневзвешенное время затухания люминесценции наноструктур определялось по формуле (3):

$$
\langle\tau\rangle=\frac{\sum_{i} A_{i} \tau_{i}^{2}}{A_{i} \tau_{i}} .
$$

Формирование сухих слоев и гибридных структур происходило путем послойного нанесения графеновых нанолент и НК методом Ленгмюра-Блоджетт [11] с помощью установки KN 2002 (KSV NIMA) на диэлектрические стеклянные подложки с предварительно напыленными титановыми планарными контактами и без них. Для напыления контактов была использована установка вакуумного физического напыления PVD 75 (Kurt J. Lesker, США). Ширина зазора между планарными контактами не превышала $10 \mu \mathrm{m}$.

Перед формированием сухих слоев коллоидный раствор НК был отмыт от избытка молекул стабилизатора с помощью процедуры осаждения НК. К объему НК в хлороформе $(100-200 \mu 1)$ добавлялся такой же объем метанола, после чего смесь была интенсивно перемешана. Затем НК, выпавшие из раствора, были осаждены при помощи центрифугирования в течение 1 минуты на скорости $10000 \mathrm{rpm}$. Данная процедура позволяет получать нанокристаллы с минимальной поверхностной концентрацией молекул стабилизатора, что позволило добиться минимального расстояния между НК в формируемых слоях.

Формирование и перенос слоев НК происходил на поверхности деионизированной воды с удельным сопротивлением $\sim 18 \mathrm{M} \Omega / \mathrm{cm}$. Поверхность воды перед процессом формирования слоя НК очищалась от посторонних частиц с помощью воздушного насоса до момента, когда сила поверхностного натяжения пленки воды опускалась ниже $0.01 \mathrm{mN} / \mathrm{cm}$, что соответствует чистой поверхности воды по спецификациям прибора. Затем на поверхность воды выкапывался раствор вещества, после чего установку оставляли на 30 минут для того, чтобы молекулы растворителя испарились с поверхности воды, а частицы слоя пришли в равновесное состояние. Далее производился процесс формирования слоя и его переноса на подложку. Формирование и перенос слоя КТ производилось при достижении силы поверхностно натяжения $30 \mathrm{mN} / \mathrm{cm}$. Для слоев НП сила поверхностного натяжения пленки при переносе на подложку составила $56 \mathrm{mN} / \mathrm{cm}$. Слои графеновых нанолент 


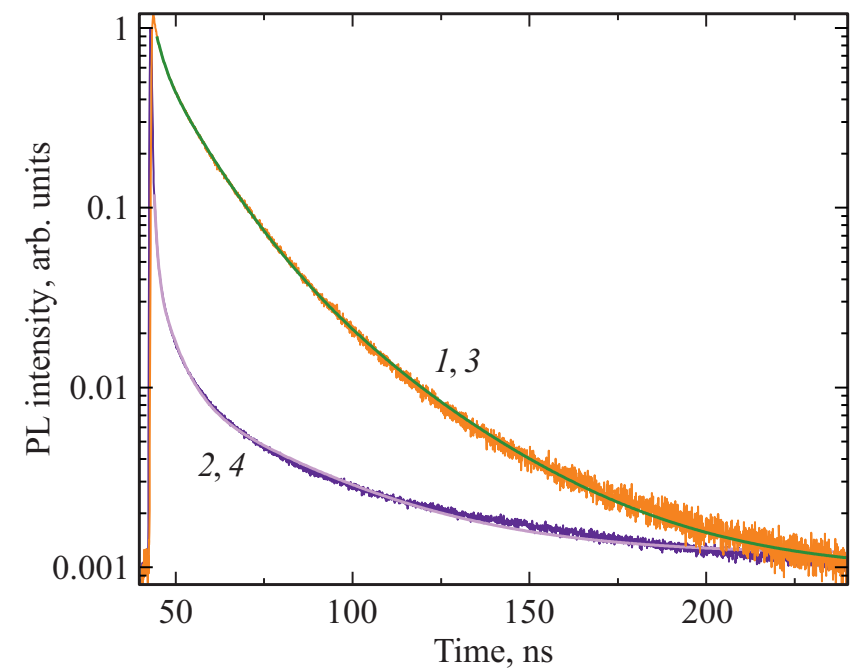

Рис. 2. Кинетика люминесценции НК в толуоле: экспериментальные данные $(1,2)$ и их аппроксимация $(3,4)$ по формуле (2) для CdSe/ZnS КТ $(1,3)$ и CdSe НП $(2,4)$.

были перенесены при силе поверхностного натяжения $41 \mathrm{mN} / \mathrm{cm}$.

\section{Результаты и обсуждение}

\section{Оптические и фотофизические свойства НК}

На рис. 1 приведены спектры поглощения и люминесценции коллоидных растворов НК в толуоле, использованных в работе.

Из рис. 1 видно, что в спектре поглощения КТ полоса экситонного поглощения имеет максимум на длине волны $570 \mathrm{~nm}$. В спектре поглощения НП наблюдаются две узкие полосы экситонного поглощения с максимумами на длинах волн $460 \mathrm{~nm}$ и $435 \mathrm{~nm}$. Эти полосы соответствуют электронным переходам с участием тяжелой и легкой дырок, соответственно [12]. Наличие наклона спектра поглощения НП в области 470-700 nm обусловлено релеевским рассеянием света, поскольку латеральные размеры НП $(300 \mathrm{~nm})$ сопоставимы с длиной волны падающего на образец света. Дополнительные полосы поглощения на длинах волн 510 и $550 \mathrm{~nm}$ в спектре НП говорят о наличии в растворе фракции пластинок с большей толщиной.

По рис. 1 видно, что ширина полос поглощения и люминесценции у НП гораздо меньше, чем у КТ. Это объясняется тем, что у НП, в отличие от КТ, эффект размерного квантования проявляется только в направлении роста толщины НП, которая одинакова для всех НП в ансамбле. При этом разброс по латеральным размерам НП в ансамбле никак не влияет на положение полос экситонного поглощения и люминесценции. Помимо этого стоит отметить, что максимум полосы экситонной люминесценции сдвинут только на $5 \mathrm{~nm}$ в область меньших энергий относительно перехода с участием тяжелой дырки с максимумом на $460 \mathrm{~nm}$. Полосы люминесценции в области $550-700 \mathrm{~nm}$ относятся к фракциям НП с большим количеством монослоев $\mathrm{CdSe}$, чем в основной фракции, а широкая неструктурированная полоса в области 500-700 nm относится к дефектной люминесценции $\mathrm{CdSe} H$ Н, обусловленной наличием оборванных связей на поверхности НП.

На рис. 2 представлены кривые затухания люминесценции КТ и НП в растворе толуола. Из рис. 2 видно, что экситонная люминесценция $\mathrm{CdSe}$ НП и $\mathrm{CdSe} / \mathrm{ZnS}$ КТ характеризуется существенно разными временами. Для обоих типов образцов распад люминесценции аппроксимируется трехэкспоненциальной зависимостью, параметры аппроксимации представлены в таблице. Для $\mathrm{CdSe} / \mathrm{ZnS}$ КТ наличие мультиэкспоненциального распада экситонной люминесценции традиционно связывается со способностью КТ спонтанно переключаться между состояниями, характеризующимися разной скоростью безызлучательной релаксации электронного возбуждения. Причина такого спонтанного переключения до сих пор является причиной дискуссии научного сообщества и на данный момент объясняется наличием дополнительного заряда в КТ и присутствием на их поверхности ловушечных состояний [13]. Следует отметить, что компонента с характерным временем затухания $\sim 40 \mathrm{~ns}$ обусловлена наличием замедленной люминесценции с участием дефектных состояний на поверхности $\mathrm{CdSe} / \mathrm{ZnS}$ KT $[14,15]$, а две оставшиеся компоненты с временами $\sim 3 \mathrm{~ns}$ и $\sim 15 \mathrm{~ns}$ связаны с экситонной люминесценцией КТ в состоянии с разной эффективностью безызлучательной релаксации экситона.

Согласно теоретическим представлениям, экситонная люминесценция $\mathrm{CdSe} \mathrm{HП}$ должна характеризоваться временами порядка $1 \mathrm{~ns}$, поскольку НП представляют собой квантовую яму, в которой кулоновское взаимодействие между электроном и дыркой в экситоне существенно сильнее, чем у сферических КТ [16]. Из данных, приведенных в таблице, видно, что в распаде экситонной люминесценции НП помимо компоненты с характерным временем затухания $\sim 1 \mathrm{~ns}$ [17] присутствуют еще две компоненты с характерными временами $\sim 6 \mathrm{~ns}$ и $\sim 45 \mathrm{~ns}$. Мы полагаем, что последние две компоненты связаны с замедленной люминесценцией с участием дефектных состояний на поверхности НП.

\section{Люминесцентные свойства гибридных структур}

Для формирования гибридных структур на основе полупроводниковых НК (КТ и НП) и графеновых нанолент применялась методика формирования и послойного нанесения тонких пленок Ленгмюра-Блоджетт на диэлектрическую подложку и подложку с титановыми микроконтактами. Подробнее процесс формирования тонких слоев НП и КТ рассмотрен в разделе „Материалы и Методы“.

На рис. 3 приведены люминесцентные изображения образцов гибридных структур НК/Графеновые нанолен- 

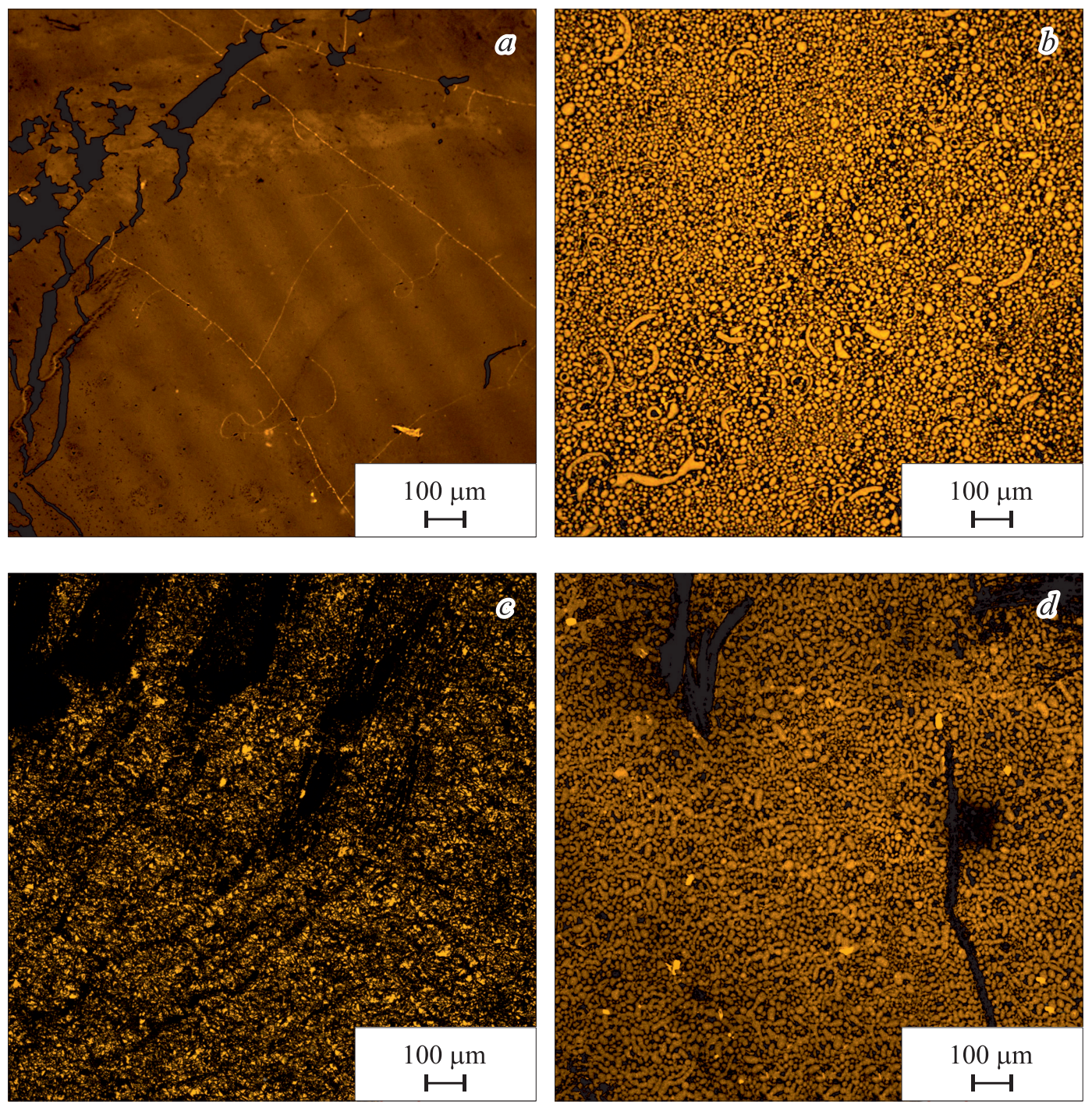

Рис. 3. Люминесцентные изображения сухих слоев $\mathrm{CdSe} / \mathrm{ZnS}$ KT $(a, c)$ и $\mathrm{CdSe}$ НП $(b, d)$, нанесенных на диэлектрическую подложку $(a, b)$ и на графеновые наноленты $(c, d)$. Возбуждение люминесценции лазером с длиной волны $405 \mathrm{~nm}$.

ты, сформированных на диэлектрической подложке и титановых контактах

По рис. 3 видно, что КТ (рис. 3 a,c) формируют монослой с малым числом разрывов на достаточно большой площади (до $1 \mathrm{~mm}^{2}$ ). При этом присутствуют небольшие по площади включения, содержащие более 1 монослоя КТ. В случае CdSe НП (рис. $3, b, d$ ) также наблюдается относительно однородный слой. Однако при большем увеличении видно, что слой НП представляет собой островковую пленку, а форма и размер островков указывают на то, что они состоят из большого числа агрегатов НП.

На рис. 4 представлены кривые затухания люминесценции $\mathrm{CdSe} / \mathrm{ZnS}$ КТ и CdSe НП в коллоидном растворе, на диэлектрической подложке, и в составе гибридных структур с графеновыми нанолентами.

На рис. 4, $а$ приведены кривые затухания люминесценции $\mathrm{CdSe} / \mathrm{ZnS}$ KT, свидетельствующие об эффективном тушении люминесценции при переходе КТ из раствора к сухим слоям на диэлектрической подложке и еще более выраженное тушение при нанесении КТ на слой графеновых нанолент.

В случае CdSe HП, кривые затухания люминесценции которых представлены на рис. 4, $b$, наблюдается совершенно другая картина. Переход от раствора к сухим слоям на диэлектрической подложке и к слоям на графеновых нанолентах приводит к увеличению среднего времени затухания люминесценции НП. Это не позволяет оценить эффективность взаимодействия НП с графеновыми нанолентами в структурах на основе анализа их люминесцентных свойств.

На рис. 5 приведены диаграммы с характерными временами затухания люминесценции $\mathrm{CdSe} / \mathrm{ZnS}$ КТ и $\mathrm{CdSe}$ НП, полученных при аппроксимации экспериментальных кривых приведенных на рис. 6, трехэкспоненциальной функцией согласно формуле (2). 

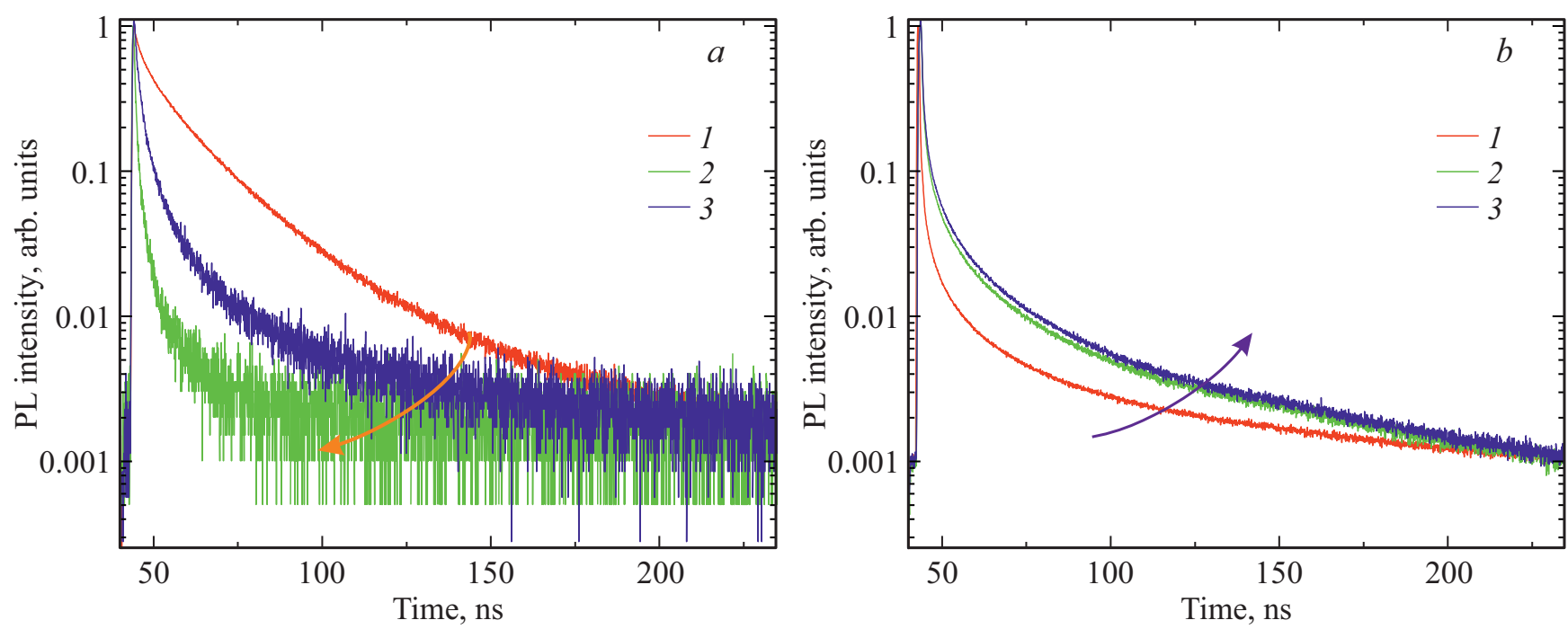

Рис. 4. Кинетика люминесценции CdSe/ZnS KT $(a)$ и CdSe НП $(b)$ в коллоидном растворе $(1)$, на диэлектрической подложке $(2)$ и в составе гибридных структур с многослойными графеновыми нанолентами (3).
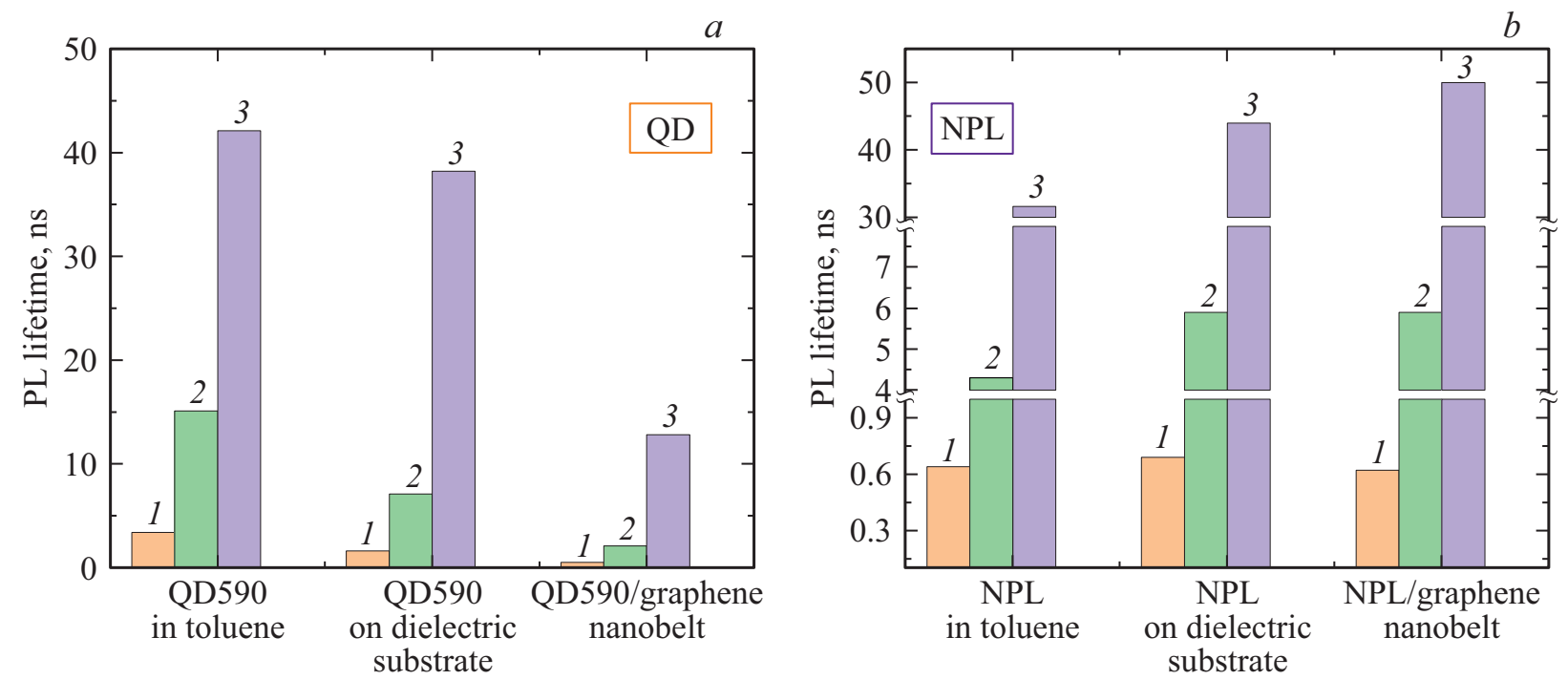

Рис. 5. Характерные времена затухания люминесценции $\tau_{1}(1), \tau_{2}(2)$ и $\tau_{3}(3) \mathrm{CdSe} / \mathrm{ZnS} \mathrm{KT}(a)$ и CdSe $\mathrm{H \Pi}(b)$ в коллоидном растворе, на диэлектрической подложке и в составе гибридных структур с графеновыми нанолентами, полученные при аппроксимации экспериментальных кривых затухания люминесценции рис. 4.

Согласно данным, приведенным на рис. 5, для оболочечных $\mathrm{CdSe} / \mathrm{ZnS}$ KT во всех фракциях наблюдается симбатное сокращение характерных времен затухания люминесценции при переходе от раствора к слоям на диэлектрической подложке и графеновых нанолент. Наблюдаемое изменение люминесцентных свойств КТ является типичным и свидетельствует об увеличении взаимодействия КТ - КТ в сухих слоях и об эффективном взаимодействии сухого слоя КТ со слоем графеновых нанолент [17]. Следует отметить, что в структурах CdSe HK с графеном может быть реализован как эффективный перенос энергии по механизму FRET [18], так и фотоиндуцированный перенос заряда [19]. Для структур НК/графеновые наноленты, исследуемых в данной работе, не представляется возможным оценить какой именно механизм взаимодействия компонентов структуры приводит к изменению проводимости структур, т.е. к изменению концентрации основных носителей заряда в графеновых нанолентах. При этом очевидно, что оба механизма вносят вклад в тушение люминесценции КТ в составе структур.

B случаe CdSe HП наблюдается противоположная картина. Так, для фракции $\mathrm{CdSe} \mathrm{HП}$, характеризующейся самым коротким временем затухания люминесценции, при переходе от коллоидного раствора к сухим слоям изменения времени затухания практически не происходит. В то же время, для двух остальных люминесцирующих фракций НП, характеризующихся большими 

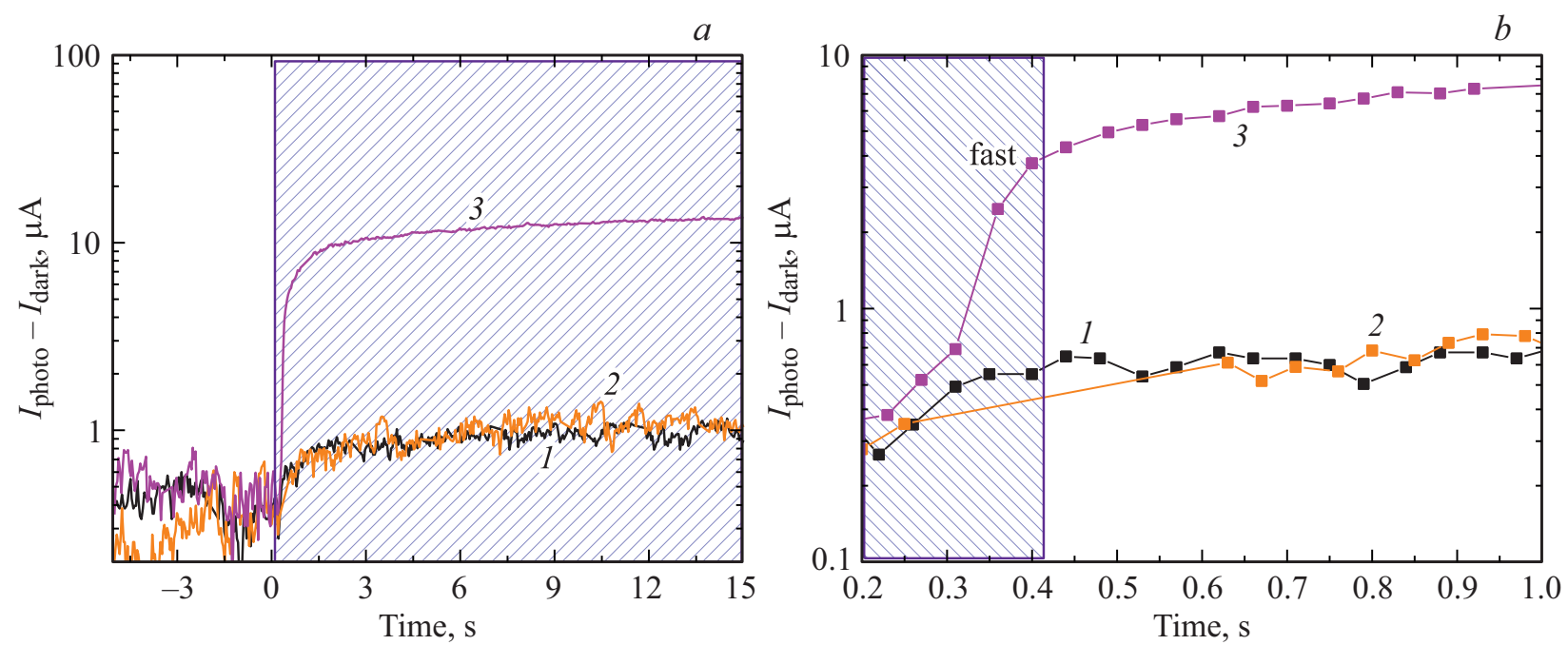

Рис. 6. Временная зависимость амплитуды фотоотклика графена (1) и гибридных структур с CdSe/ZnS KT (2) и CdSe HП (3) во время облучения лазером с длиной волны $405 \mathrm{~nm}$ и мощностью $5 \mathrm{~mW}$ - заштрихованная область (a); быстрая фаза фотоотклика $(b)$.

временами, переход от раствора к сухим слоям сопровождается увеличением характерных времен. В случае НП заметный вклад в экситонную люминесценцию вносят компоненты, связанные с замедленной люминесценцией с участием метастабильных поверхностных состояний (см. рис. 5,b). Поэтому данное поведение люминесцентных свойств НП, скорее всего, связано с резким увеличением влияния поверхностных дефектных состояний при переходе от коллоидного раствора к агрегатам НП в сухих слоях, что в свою очередь объясняется сложной морфологией полученных слоев НП. Отсутствие сокращения характерных времен затухания люминесценции НП в составе гибридных структур может быть связано с тем, что в данном случае слой НК слой состоит из нескольких слоев хаотично ориентированных относительно друг друга НП, свернутых в свитки. В этом случае эффективное взаимодействие следует ожидать только для НП, которые имеют непосредственный контакт со слоем графеновых нанолент, которое, скорее всего, приводит к полному тушению люминесценции данных НП. Для НП, не имеющих непосредственного контакта с графеновыми нанолентами, взаимодействие между компонентами гибридной структуры малоэффективно и не приводит к заметному изменению люминесцентных характеристик этих НП. Следует также отметить, что феномен мультиэкспоненциального затухания люминесценции НП на данный момент практически не исследован. Поэтому неясно, с какими именно особенностями строения кристаллической решетки или морфологии поверхности НП связано наличие замедленной люминесценции и каким образом взаимодействие НП в составе гибридных структур с акцептором заряда или энергии должно сказываться на поведении их замедленной экситонной люминесценции.

\section{Электрические свойства гибридных структур на основе графена и CdSe/ZnS KT или CdSe HП}

Отсутствие тушения люминесценции CdSe HП в составе гибридных структур не позволяет оценить эффективность взаимодействия компонентов структуры по изменению люминесцентных свойств НП. В предположении, что взаимодействие НП с графеновыми нанолентами в составе структур приводит к полному тушению люминесценции части НП, были исследованы темновая и фотоиндуцированная проводимости гибридных структур НК/Графеновые наноленты. Для этого гибридные структуры формировались на специальных стеклянных подложках с предварительно напыленными титановыми микроконтактами. На рис. 6 приведены зависимости тока, протекающего через образец графеновых нанолент, и гибридных структур НК/графеновые наноленты во время периодического облучения полупроводниковым лазером с длиной волны $405 \mathrm{~nm}$ и мощностью падающего на образцы излучения $5 \mathrm{~mW}$.

На рис. 6 видно, что, несмотря на эффективное тушение люминесценции $\mathrm{CdSe} / \mathrm{ZnS}$ KT при переходе от сухого слоя на диэлектрической подложке к гибридным структурам (рис. 5,a), монослой КТ практически не дает никакого вклада в фотопроводимость гибридных структур. Это свидетельствует о незначительном изменении концентрации основных носителей заряда в графеновых нанолентах в результате переноса энергии/заряда от КТ. В то же время в структурах с CdSe HП освещение излучением, которое могут эффективно поглощать НП, приводит к многократному увеличению проводимости структур и, самое главное, к заметному увеличению скорости нарастания проводимости при включении внешнего облучения, которая составляет в начальный период $1.7 \mu \mathrm{A}$ для графена, $0.65 \mu \mathrm{A}$ для гибридных структур с КТ, и $13.6 \mu \mathrm{A}$ для гибридных структур с НП (рис. 6, $b$ ). 
Это свидетельствует об эффективной передаче энергии/заряда от $\mathrm{CdSe}$ НП к графеновым нанолентам в структурах [20] и косвенным образом подтверждает предположение о том, что НП, имеющие непосредственный контакт с графеновыми нанолентами, оказываются полностью потушенными.

\section{Заключение}

В работе сформированы гибридные структуры на основе двух разных типов полупроводниковых НК сферических оболочечных $\mathrm{CdSe} / \mathrm{ZnS}$ КТ и $\mathrm{CdSe} \mathrm{HП,} \mathrm{с}$ графеновыми нанолентами и исследованы их люминесцентные и фотоэлектрические свойства. Анализ люминесцентных свойств НК и гибридных структур на их основе показал, что оба типа CdSe HK характеризуются мультиэкспоненциальным распадом экситонной люминесценции. Показано, что мультиэкспоненциальный характер распада экситонной люминесценции $\mathrm{CdSe}$ НП обусловлен наличием замедленной люминесценции с характерными временами затухания $\sim 6 \mathrm{~ns}$ и $\sim 45 \mathrm{~ns}$, возникновение которой может быть обусловлено наличием поверхностных дефектных состояний (trap-states). Установлено, что при переходе от коллоидных растворов к сухим слоям времена затухания экситонной люминесценции CdSe HП возрастают за счет увеличения характерных времен затухания фракций, связанных с замедленной экситонной люминесценцией НП. Для установления природы замедленной экситонной люминесценции в CdSe HП и выяснения ее закономерностей в составе гибридных структур с акцептором энергии или заряда необходимо проведение отдельного исследования.

Анализ фотоэлектрических свойств гибридных структур НК/графеновые наноленты показал, что одного монослоя $\mathrm{CdSe} / \mathrm{ZnS}$ KT, нанесенного на графеновые наноленты, недостаточно для заметного изменения проводимости графеновых нанолент при освещении структур. Установлено, что использование относительно толстого слоя CdSe НП, который, скорее всего, состоит из свернутых в свитки хаотично расположенных относительно друг друга НП, в составе гибридных структур приводит к многократному увеличению амплитуды и скорости нарастания проводимости графеновых нанолент по сравнению с исходной собственной проводимостью при освещении образцов светом с длиной волны $405 \mathrm{~nm}$. Это указывает на эффективное взаимодействие НП, по крайней мере небольшой их части в слое, с графеновыми нанолентами. Таким образом, полученные результаты показывают перспективность использования $\mathrm{CdSe}$ НП в составе гибридных структур в качестве эффективного донора энергии/заряда.

\section{Финансирование работы}

Работа выполнена при поддержке Министерства науки и высшего образования Российской Федерации, госзадание № 2019-1080.

\section{Конфликт интересов}

Авторы заявляют, что у них нет конфликта интересов.

\section{Список литературы}

[1] Kovalenko M.V., Manna L., Cabot A., Hens Z., Talapin D.V., Kagan C.R., Guyot-Sionnnest P. // ACS Nano. 2015. V. 9. N 2. P. 1012.

[2] Talapin D.V., Lee J.S., Kovalenko M.V., Shevchenko E.V. // Chem. Rev. 2010. V. 110. N 1. P. 389.

[3] Amelia M., Lincheneau C., Silvi S., Credi A. // Chemical Society Reviews. 2012. V. 41. N 17. P. 5728.

[4] Pelton M., Ithurria S., Schaller R.D., Dolzhnikov D.S., Talapin D.V. // NanoLett. 2012. V. 12. N 12. P. 6158.

[5] Chen Z., Nadal B., Mahler B., Aubin H., Dubertret B. // Adv. Funct. Mater. 2014. V. 24. N 3. P. 295.

[6] Guzelturk B., Kelestemur Y., Olutas M., Delikanli S., Demir H.V. // ACS Nano. 2014. V. 8. N 7. P. 6599.

[7] Dabbousi B.O., Rodriguez-Viejo J., Mikulec F.V., Heine J.R., Mattoussi H., Ober R., Jensen K.F., Bawendi M.G. // J. Phys. Chem. B. 1997. V. 101. N 46. P. 9463.

[8] Ithurria S., Bousquet G., Dubertret B. // J. American Chem. Soc. 2011. V. 133. N 9. P. 3070.

[9] Bouet C., Mahler B., Nadal B., Abecassis B., Tessier M.D., Ithurria S., Dubertret B. // Chemistry of Materials. 2013. V. 25. N 4. P. 639.

[10] Kubin R.F., Fletcher A.N. // J. Luminescence. 1982. V. 27. N 4. P. 455.

[11] Zasadzinski J.A., Viswanathan R., Madsen L., Garnaes J., Schwartz D.K. // Science. 1994. V. 263. N 5154. P. 1726.

[12] Tessier M.D., Javaux C., Maksimovic I., Loriette V., Dubertret B. // ACS Nano. 2012. V. 6. N 8. P. 6751.

[13] Yuan G., Gómez D.E., Kirkwood N., Boldt K., Mulvaney P. // ACS Nano. 2018. V. 12. N 4. P. 3397.

[14] Rabouw F.T., Kamp M., van Dijk-Moes R.J., Gamelin D.R., Koenderink A.F., Meijerink A., Vanmaekelbergh D. // Nano Lett. 2015. V. 15. N 11. P. 7718.

[15] Veamatahau A., Jiang B., Seifert T., Makuta S., Latham K., Kanehara M., Tachibana Y. // Physical Chemistry Chemical Physics. 2015. V. 17. N 4. P. 2850.

[16] Ithurria S., Tessier M.D., Mahler B., Lobo R.P.S.M., Dubertret B., Efros A.L. // Nature Materials 2011. V. 10. N 12. P. 936.

[17] Reznik I.A., Gromova Y.A., Zlatov A.S., Baranov M.A., Orlova A.O., Moshkalev S.A., Maslov V.G., Baranov A.V., Fedorov A.V. // Optics and Spectrosc. 2017. V. 122. N 1. P. 119.

[18] Gromova Y.A., Reznik I.A., Vovk I.A., Rackauskas S., Alaferdov A.V, Orlova A.O, Moshkalev S.A, Baranov A.V, Fedorov A.V. // MRS Online Proceedings Library Archive. 2015. V. 15. N 9. P. 1787.

[19] Kolesova E.P., Cleary O., Gun'ko Y.K., Maslov V.G., Orlova A.O. // J. Phys.: Conference Ser. 2018. V. 1092. N 1. P. 012057.

[20] Sun Z., Liu Z., Li J., Tai G.A., Lau S.P., Yan F. // Advanced Mater. 2012. V. 24. N 43. P. 5878. 